\title{
Substitution of wheat straw with sugarcane bagasse in low-forage diets fed to mid-lactation dairy cows: Milk production, digestibility, and chewing behavior
}

\author{
M. Molavian, ${ }^{1}$ G. R. Ghorbani, ${ }^{1 *}$ H. Rafiee,,${ }^{1 *}$ and K. A. Beauchemin ${ }^{2}$ \\ ${ }^{1}$ Department of Animal Sciences, College of Agriculture, Isfahan University of Technology, Isfahan 84156-83111, Iran \\ ${ }^{2}$ Lethbridge Research and Development Centre, Agriculture and Agri-Food Canada, Lethbridge, AB, Canada T1J 4B1
}

\begin{abstract}
Sugarcane bagasse (SB) is a low-quality roughage source that is often plentiful during times of forage shortage. It is generally less costly compared with other conventional sources of forage. We hypothesized that SB could be used as a source of roughage for dairy cattle by replacing wheat straw (WS), another low-quality forage. This study evaluated the effects of replacing WS with SB in diets offered to mid-lactation dairy cows on milk production and fatty acid profile, intake, digestibility, chewing activity, and ruminal fermentation. Nine multiparous Holstein cows averaging (mean \pm standard deviation) $105 \pm 12 \mathrm{~d}$ in milk, $42.1 \pm 2.9$ $\mathrm{kg}$ of milk/d, and $617 \pm 59 \mathrm{~kg}$ of body weight were used in a replicated $3 \times 3$ Latin square with 21 -d periods. Treatments were (\% of dietary dry matter, DM): (1) 0SB, diet containing $0 \% \mathrm{SB}$ and $27 \% \mathrm{WS}$, (2) 9SB, diet containing $9 \% \mathrm{SB}$ and $18 \% \mathrm{WS}$, and (3) $18 \mathrm{SB}$, diet containing $18 \% \mathrm{SB}$ and $9 \%$ WS. Sugarcane bagasse had greater organic matter (OM; 94.1 vs. 85.1\% of DM), neutral detergent fiber (NDF; 86.2 vs. $76.4 \%$ of $\mathrm{DM}$ ), acid detergent fiber (ADF; 62.9 vs. $45.2 \%$ of $\mathrm{DM}$ ), and lignin (19.9 vs. $10.3 \%$ of $\mathrm{DM})$ concentration, but less crude protein (CP; 2.63 vs. $3.72 \%$ of DM) concentration than WS. Sugarcane bagasse also had greater physically effective NDF (total dietary NDF multiplied by $\%$ of TMR on the $8-\mathrm{mm}+19-\mathrm{mm}$ sieves, peNDF $_{8} ; 63.2$ vs. $40.6 \%$ of DM) and undegraded NDF after $288 \mathrm{~h}$ of incubation $\left(\mathrm{uNDF}_{288} ; 35.5\right.$ vs. $21.2 \%$ of DM) contents than WS. The undegraded NDF after 30 $\mathrm{h}$ of incubation $\left(\mathrm{uNDF}_{30}\right)$ content was similar for all diets; however, peNDF $_{8}$ concentration and proportion of long particles (retained on a 19-mm sieve) increased linearly as SB inclusion in the diets increased. Cows in-
\end{abstract}

Received March 10, 2020.

Accepted April 21, 2020.

*Corresponding authors: hrafiee@alumni.ut.ac.ir and Ghorbani@cc iut.ac.ir creasingly sorted against long particles as SB replaced WS. Intakes of DM $(26.53 \mathrm{~kg} / \mathrm{d})$ and NDF $(8.58 \mathrm{~kg} / \mathrm{d})$ did not differ among the treatments, but intakes of OM and $\mathrm{CP}$ decreased, whereas $\mathrm{ADF}$ and $\mathrm{uNDF}_{288}$ intakes increased with SB inclusion level. Total-tract digestibilities of OM, CP, and NDF decreased linearly as SB replaced WS. Milk yield $(37.0 \mathrm{~kg} / \mathrm{d})$, energy-corrected milk yield (ECM; $38.2 \mathrm{~kg} / \mathrm{d})$, feed efficiency $(1.44 \mathrm{~kg}$ ECM yield/kg DM intake), and milk composition (fat, $3.89 \%$; true protein, $2.90 \%$ ) did not differ among diets. Increasing SB concentration of the diet linearly increased rumination time, but ruminal $\mathrm{pH}$ (ruminocentesis, $4 \mathrm{~h}$ after feeding) decreased. Total volatile fatty acid concentration increased linearly, whereas acetate: propionate decreased linearly, as SB replaced WS. The results indicate that replacement of WS with increasing levels of $\mathrm{SB}$ in low-forage diets with similar $\mathrm{uNDF}_{30}$ concentrations did not affect performance of mid-lactation dairy cows. We conclude that SB can be used as a fiber source in diets fed to dairy cows in mid-lactation; however, the decrease in total-tract digestibility of diets may decrease lactational performance when fed to highproducing dairy cows.

Key words: wheat straw, sugarcane bagasse, undegradable neutral detergent fiber, byproduct

\section{INTRODUCTION}

Providing adequate fiber to meet the needs of dairy cows is critical to maintaining rumen function, milk fat concentration, and animal performance. Two forage sources commonly used in dairy cow diets worldwide are corn silage and alfalfa hay or silage. These forages are highly digestible and therefore maintain high intake and milk production (Wang et al., 2014; Ferraretto et al., 2015). However, availability of high-quality forages is sometimes limited because of unfavorable weather conditions, or shortage of land or water, particularly in arid regions of the world. Consequently, crop byproducts and other roughage sources are often used in dairy cow rations. 
For example, wheat straw (WS) is a crop byproduct that is abundantly available, with an estimated 750 million metric tonnes produced annually worldwide (FAOSTAT, 2016). However, the low digestibility and low nutritive value (NDF and $\mathrm{CP}$ about 80 and $2.5 \%$ of DM, respectively) of WS may compromise DMI, and consequently milk production of high-producing dairy cows (Eastridge et al., 2009; Wang et al., 2014). Despite its low digestibility, WS is sometimes included in dairy diets as a source of physically effective fiber (peNDF; Kahyani et al., 2019a,b).

Sugarcane (Saccharum officinarum L.) is a perennial plant with high potential DM yield that is widely used in the production of sugar and ethanol in tropical and subtropical climates. An important byproduct from sugarcane processing is sugarcane bagasse (SB; Costa et al., 2015). Sugarcane bagasse is often plentiful during times of forage shortage and it is generally less costly compared with other conventional sources of forage (Daniel et al., 2014; de Almeida et al., 2018). However, $\mathrm{SB}$ has low nutritive value; its NDF concentration is $>80 \%$ of DM and its CP concentration is about $1.5 \%$ of DM. Therefore, when incorporating SB in dairy cow diets it is necessary to include a high proportion of concentrate to meet the digestible energy and CP requirements of the animals (Sá Neto et al., 2014). Alternatively, SB may be a source of peNDF, and used similarly to WS in dairy cow diets.

Most of the work to evaluate SB as a livestock feed has been conducted with beef cattle. Leme et al. (2003) substituted SB for corn grain and citrus pulp in the diet of beef cattle, with soybean meal inclusion to compensate for the low CP concentration of SB. Pate (1981) replaced shelled corn and citrus pulp with SB, and increased the inclusion of cottonseed meal to maintain dietary $\mathrm{CP}$ concentration. In both experiments, ADG decreased with increasing SB inclusion in diets.

Although studies indicate that SB can be used as a source of roughage for beef cattle, only limited information is available that compares SB to other fiber sources for dairy cows (Corrêa et al., 2003; Sá Neto et al., 2014; de Almeida et al., 2018). de Almeida et al. (2018) reported that diets with increasing concentrations of SB ( 45 to $60 \%$ of DM), with SB replacing spineless cactus, decreased DMI and milk yield of low-producing dairy cows. Freitas et al. (2018) noted that replacing spineless cactus with SB comprising 30 to $54 \%$ of dietary DM reduced milk yield from 22 to $16 \mathrm{~kg} / \mathrm{d}$. Corrêa et al. (2003) also reported that using SB silage instead of corn silage decreased DMI and milk yield. The decrease in DMI and milk yield of cows observed in those studies can be attributed mainly to high inclusion level, and increased NDF and undegraded NDF (uNDF) concentrations of the diets, and a decrease in total-tract digestibility because SB replaced higher quality fiber sources.

Given that the composition of WS is similar to that of SB, we hypothesized that partially replacing WS with SB in a low-forage diet would maintain DMI and performance of mid-lactation dairy cows. Therefore, the objective of the present study was to investigate the effects of partial replacement of WS with SB on performance, digestibility, chewing activity, and ruminal fermentation of dairy cows in mid-lactation.

\section{MATERIALS AND METHODS}

All animal procedures were conducted with protocols approved by the Animal Care and Use Committee of the Iranian Council of Animal Care (1995). The experiment was conducted from September to November 2018, at the Farm Animal Research and Teaching Unit of Isfahan University of Technology (Isfahan, Iran).

\section{Crop Byproducts and In Situ NDF Degradability}

A threshing machine (designed to separate cereal grains from straw) with a $10-\mathrm{mm}$ theoretical length of cut (Golchin Trasher Hay Co., Isfahan, Iran) was used to finely chop the WS. The purchased SB had about $46 \% \mathrm{DM}$; it was kept for 3 to $4 \mathrm{~d}$ in a warm open environment before feeding to the cows. The chemical composition of the WS and SB is presented in Table 1, with the physical properties presented in Table 2.

An in situ study was conducted to measure uNDF in WS, SB, and TMR, according to the method described by Kahyani et al. (2019a,b). For the incubations, 2 nonlactating Holstein ruminally cannulated dairy cows were offered a high-forage TMR diet $(25 \%$ SB, $50 \%$ WS, $25 \%$ concentrate mix; DM basis) as recommended by Krizsan and Huhtanen (2013). The cows received this diet for $2 \mathrm{wk}$ before starting the incubation. Dried samples $\left(60^{\circ} \mathrm{C}\right.$ for $\left.48 \mathrm{~h}\right)$ of WS, SB, and TMR were ground using a Wiley mill (Arthur H. Thomas, Philadelphia, PA) to pass a $1-\mathrm{mm}$ sieve, and $0.5 \mathrm{~g}$ of each feed was weighed into Ankom F57 bags $(5 \times 4 \mathrm{~cm}$; Ankom Technology, Macedon, NY) with pore size of $25 \mu \mathrm{m}$ (Kahyani et al., 2019a,b). Samples were incubated in triplicate within each cow for $6,12,24,30$, 48, 72, and $288 \mathrm{~h}$. Triplicate empty bags (blanks) were also incubated and removed at each time to correct for possible infiltration of NDF into the sample bags. After removal, the bags were soaked in cold water and washed in a washing machine for $12 \mathrm{~min}$, and then transferred to a forced ventilation oven $\left(60^{\circ} \mathrm{C}\right)$ for $48 \mathrm{~h}$. The equation used to correct for blanks in the calculation of NDF residue at each time point was as follows (Kahyani et al., 2019a,b): 
Table 1. Chemical characteristics of the roughage sources [mean (SD)]

\begin{tabular}{lcc}
\hline Item, \% of DM, unless otherwise stated & Wheat straw & Sugarcane bagasse \\
\hline $\mathrm{DM}, \%$ as fed & $96.4(0.1)$ & $95.5(0.02)$ \\
$\mathrm{OM}$ & $85.1(0.42)$ & $94.1(0.20)$ \\
$\mathrm{CP}$ & $3.72(0.35)$ & $2.63(0.42)$ \\
$\mathrm{NDF}$ & $76.4(1.66)$ & $86.2(1.00)$ \\
$\mathrm{ADF}$ & $45.2(0.68)$ & $62.9(0.53)$ \\
$\mathrm{ADL}$ & $10.3(0.94)$ & $19.9(0.90)$ \\
Ether extract & $0.97(0.09)$ & $0.80(0.15)$ \\
Ash & $14.9(0.42)$ & $5.94(0.20)$ \\
Acid-insoluble ash & $6.98(0.33)$ & $2.69(0.09)$ \\
$\mathrm{NFC}^{1}$ & $4.01(0.78)$ & $4.43(1.02)$ \\
$\mathrm{NE}_{\mathrm{L}}{ }^{2}$ Mcal/kg of DM & 0.50 & 0.49 \\
\hline
\end{tabular}

${ }^{1}$ Nonfiber carbohydrates $[\mathrm{NFC}=\mathrm{OM}-(\mathrm{NDF}+\mathrm{CP}+\mathrm{EE})]$, where $\mathrm{EE}=$ ether extract.

${ }^{2}$ Calculated from NRC (2001).

NDF residue $(\mathrm{g} / \mathrm{g}$ of $\mathrm{DM})=[$ (bag weight + residue $)$

- (bag weight $\times$ bag correction factor)]/

[(bag weight + sample $)-$ bag weight $]$.

The bag correction factor represents the average fractional weight change of 3 blank bags following the NDF washing procedure. The $\mathbf{u N D F}_{30}, \mathbf{u N D F}_{72}$, and $\mathbf{u N D F}_{288}$ were undegraded NDF after 30-, 72-, and 288$\mathrm{h}$ of incubation, with $\mathrm{uNDF}_{288}$ considered undegradable NDF. Potentially degradable NDF $\left(\mathbf{p d N D F} \mathbf{N}_{\mathbf{2 8 8}}\right)$ was calculated as the difference between total NDF and $\mathrm{uNDF}_{288}$ (Lopes et al., 2015a). The uNDF and pdNDF are presented as \% of DM.

\section{Cows, Management, and Treatments}

Nine multiparous Holstein cows with $105 \pm 12$ DIM, $42.1 \pm 2.9 \mathrm{~kg}$ of milk/d, $617 \pm 59.5 \mathrm{~kg}$ of BW, and a BCS of $2.9 \pm 0.3$ (mean \pm SEM, using a 5 -point scale where $1=$ emaciated and $5=$ obese; Edmonson et al., 1989 ) at the beginning of the experiment were used. The cows were individually housed in box stalls $(4 \times 4$ $\mathrm{m}$ ) within a roofed barn with open sides. Clean wood shavings were used as bedding, and refreshed twice daily. Cows had continuous access to concrete feed bunks and automatic water troughs. The cows were moved to the box stalls 2 wk before the start of the experiment to allow them to adapt to the pen. At the end of the

Table 2. Physical attributes and NDF degradation characteristics of the roughage sources

\begin{tabular}{|c|c|c|c|c|}
\hline Item & Wheat straw & Sugarcane bagasse & SEM & $P$-value \\
\hline \multicolumn{5}{|c|}{ Particle size distribution, \% DM retained on sieve } \\
\hline $19 \mathrm{~mm}$ & 2.6 & 24.9 & 2.04 & $<0.01$ \\
\hline $1.18 \mathrm{~mm}$ & 41.2 & 23.6 & 1.99 & $<0.01$ \\
\hline Pan & 5.7 & 3.1 & 0.60 & 0.01 \\
\hline $\operatorname{peNDF}_{8}, \%$ of DM & 40.6 & 63.2 & 2.11 & $<0.01$ \\
\hline $\operatorname{peNDF}_{1.18}, \%$ of DM & 72.1 & 83.5 & 0.48 & $<0.01$ \\
\hline \multicolumn{5}{|c|}{ NDF degradation characteristics (\% of DM) } \\
\hline $\mathrm{uNDF}_{30}$ & 54.2 & 65.1 & 0.68 & $<0.01$ \\
\hline $\mathrm{uNDF}_{30}, \%$ of NDF & 70.8 & 75.6 & 0.88 & $<0.01$ \\
\hline $\operatorname{pdNDF}_{30}{ }^{4}$ & 22.2 & 21.1 & 0.68 & 0.16 \\
\hline $\mathrm{uNDF}_{72}$ & 35.3 & 45.8 & 2.03 & $<0.01$ \\
\hline $\mathrm{uNDF}_{72}, \%$ of NDF & 46.2 & 53.2 & 2.40 & 0.04 \\
\hline $\mathrm{pdNDF}_{72}$ & 41.1 & 40.4 & 2.04 & 0.73 \\
\hline
\end{tabular}

${ }^{1}$ peNDF $_{8}$ and peNDF ${ }_{1.18}=$ physically effective NDF determined as NDF concentration (\% of DM) of forage or TMR multiplied by corresponding physical effectiveness factors $\left(\right.$ pef $_{8}$ and pef $_{1.18}$ ), respectively, determined by sieving fresh sample.

${ }^{2}$ Geometric mean of particle size (GMPS) and standard deviation of particle size (SDPS) were calculated as described by the American Society of Agricultural Engineers (ASABE, 2003, method S319.3).

${ }^{3} \mathrm{uNDF}=\mathrm{NDF}$ residue after $30-, 72-$, or $288-\mathrm{h}$ in situ incubation.

${ }^{4} \mathrm{pdNDF}=$ potentially degradable NDF after $30-, 72-$, or 288 -h in situ incubation. 
Table 3. Ingredients and chemical composition of experimental diets

\begin{tabular}{|c|c|c|c|}
\hline \multirow{2}{*}{$\begin{array}{l}\text { Item, } \% \text { of DM, unless } \\
\text { otherwise stated }\end{array}$} & \multicolumn{3}{|c|}{ Treatment $^{1}$} \\
\hline & 0SB & 9SB & $18 \mathrm{SB}$ \\
\hline \multicolumn{4}{|l|}{ Ingredient } \\
\hline Wheat straw & 27.40 & 18.40 & 9.32 \\
\hline Sugarcane bagasse & 0.00 & 9.04 & 18.10 \\
\hline Ground corn grain & 21.80 & 21.80 & 21.80 \\
\hline Ground barley grain & 19.20 & 19.20 & 19.20 \\
\hline Soybean meal, $44 \% \mathrm{CP}$ & 15.00 & 15.00 & 15.00 \\
\hline Meat meal & 4.80 & 4.80 & 4.80 \\
\hline Beet pulp & 3.24 & 3.24 & 3.24 \\
\hline Fat powder ${ }^{2}$ & 3.20 & 3.20 & 3.20 \\
\hline Molasses & 2.00 & 2.00 & 2.00 \\
\hline Fish meal & 1.00 & 1.00 & 1.00 \\
\hline Sodium bicarbonate & 1.16 & 1.16 & 1.16 \\
\hline Vitamin supplement $^{3}$ & 0.32 & 0.32 & 0.32 \\
\hline Mineral supplement ${ }^{4}$ & 0.32 & 0.32 & 0.32 \\
\hline Calcium carbonate & 0.28 & 0.28 & 0.28 \\
\hline Salt & 0.12 & 0.12 & 0.12 \\
\hline Magnesium oxide & 0.04 & 0.04 & 0.04 \\
\hline \multicolumn{4}{|c|}{ Chemical composition, mean (SD) } \\
\hline $\mathrm{DM}$ & $50.70(0.01)$ & $50.54(0.02)$ & $50.10(0.04)$ \\
\hline $\mathrm{OM}$ & $92.69(0.23)$ & $93.19(0.01)$ & $93.30(0.07)$ \\
\hline $\mathrm{CP}$ & $16.79(0.87)$ & $16.60(1.10)$ & $16.20(0.43)$ \\
\hline $\mathrm{NDF}$ & $31.19(0.00)$ & $32.30(0.96)$ & $33.40(0.60)$ \\
\hline Forage NDF & $23.29(0.23)$ & $24.40(0.31)$ & $25.59(0.28)$ \\
\hline $\mathrm{ADF}$ & $15.79(1.03)$ & $16.51(0.74)$ & $19.60(0.83)$ \\
\hline Ether extract & $5.75(0.17)$ & $6.32(0.12)$ & $6.22(0.23)$ \\
\hline $\mathrm{NFC}^{5}$ & $38.49(0.44)$ & $39.30(0.92)$ & $40.09(0.77)$ \\
\hline Starch & $26.69(0.90)$ & $27.00(0.16)$ & $27.69(0.33)$ \\
\hline Acid-insoluble ash & $1.23(0.02)$ & $1.15(0.01)$ & $1.14(0.06)$ \\
\hline $\mathrm{NE}_{\mathrm{L}},{ }^{6} \mathrm{Mcal} / \mathrm{kg}$ of DM & 1.68 & 1.68 & 1.68 \\
\hline \multicolumn{4}{|c|}{$\begin{array}{l}{ }^{1} 0 \mathrm{SB}=0 \% \text { sugarcane bagasse }+27.4 \% \text { wheat straw; } 9 \mathrm{SB}=9.0 \% \text { sugarcane bagasse }+18.4 \% \text { wheat straw; } \\
18 \mathrm{SB}=18.1 \% \text { sugarcane bagasse }+9.32 \% \text { wheat straw. }\end{array}$} \\
\hline \multicolumn{4}{|c|}{$\begin{array}{l}{ }^{2} \text { Extima 100, Erafeed, Selangor, Malaysia. Composition: moisture, } 0.5 \% \text {; crude fat, } 99.5 \% \text { (C14:0, 0-3\%; C16:0, } \\
80 \% \text {; C18:0, 5-10\%; C18:1, 8-12\%). }\end{array}$} \\
\hline \multicolumn{4}{|c|}{$\begin{array}{l}{ }^{3} \text { Composition: } 1,500,000 \mathrm{IU} / \mathrm{kg} \text { vitamin A; } 250,000 \mathrm{IU} / \mathrm{kg} \text { vitamin } \mathrm{D}_{3} ; 15,000 \mathrm{IU} / \mathrm{kg} \text { vitamin } \mathrm{E}, 0.5 \mathrm{~g} / \mathrm{kg} \mathrm{Cu} ; \\
0.008 \mathrm{~g} / \mathrm{kg} \text { Se; } 1.5 \mathrm{~g} / \mathrm{kg} \mathrm{Mn} ; 2 \mathrm{~g} / \mathrm{kg} \mathrm{Zn} ; 0.2 \mathrm{~g} / \mathrm{kg} \text { biotin; and } 3 \mathrm{~g} / \mathrm{kg} \text { monensin. }\end{array}$} \\
\hline \multicolumn{4}{|c|}{$\begin{array}{l}{ }^{4} \text { Composition: } 245 \mathrm{~g} / \mathrm{kg} \mathrm{Ca} ; 55 \mathrm{~g} / \mathrm{kg} \mathrm{Mg} ; 13.5 \mathrm{~g} / \mathrm{kg} \mathrm{Mn} ; 18 \mathrm{~g} / \mathrm{kg} \mathrm{Zn} ; 4.5 \mathrm{~g} / \mathrm{kg} \mathrm{Cu} ; 0.02 \mathrm{~g} / \mathrm{kg} \mathrm{I} ; 0.1 \mathrm{~g} / \mathrm{kg} \mathrm{Co} \text {; } \\
\text { and } 0.072 \mathrm{~g} / \mathrm{kg} \mathrm{Se} \text {. }\end{array}$} \\
\hline \multicolumn{4}{|c|}{$\begin{array}{l}{ }^{5} \text { Nonfiber carbohydrates }[\mathrm{NFC}=\mathrm{OM}-(\mathrm{NDF}+\mathrm{CP}+\mathrm{EE})] \text {, where } \mathrm{EE}=\text { ether extract. } \\
{ }^{6} \text { Calculated from NRC }(2001) .\end{array}$} \\
\hline
\end{tabular}

2 wk, milk production, BW, and BCS were recorded and used to allocate 3 cows to each of 3 groups. Within each group, the cows were randomly allocated to 1 of 3 treatment sequences. The experimental design was a replicated ( 3 blocks) $3 \times 3$ Latin square, with 3 dietary treatments and 3 experimental periods. Each period lasted $21 \mathrm{~d}$ with the first $16 \mathrm{~d}$ for adaptation and the last $5 \mathrm{~d}$ for sampling and data collection. The dietary treatments were (1) 0SB, diet containing $0 \% \mathrm{SB}$ and $27 \% \mathrm{WS}$, (2) 9SB, diet containing $9 \% \mathrm{SB}$ and $18 \% \mathrm{WS}$, and (3) $18 \mathrm{SB}$, diet containing $18 \% \mathrm{SB}$ and $9 \% \mathrm{WS}$.

The ingredient and chemical composition of diets are shown in Table 3. All diets contained $3.24 \%$ beet pulp (DM basis), with no other forage source other than WS or SB offered. Thus, all diets had 27:73 forage to concentrate ratio (DM basis) and differed only by proportion of SB and WS. Diets were offered twice daily at 1000 and $1700 \mathrm{~h}$, and orts were removed and weighed daily. Feed offered was adjusted daily to ensure $10 \%$ excess. All diets were formulated with the Cornell Net Carbohydrate and Protein System (version 5.0) to contain similar $\mathrm{NE}_{\mathrm{L}}$ concentrations and to meet the requirements of a multiparous cow producing $42 \mathrm{~kg}$ of milk/d with $3 \%$ true milk protein and $3.2 \%$ fat assuming a DMI of $25 \mathrm{~kg} / \mathrm{d}$.

\section{Feed Sampling and Analyses}

During the sampling period, the amount of TMR offered and refused was recorded to determine DMI. Samples of TMR were collected at feeding and refusals were collected before morning feeding during the last 5 $\mathrm{d}$ of each period and composited (by cow for orts), and stored at $-20^{\circ} \mathrm{C}$ for later analysis. The TMR and orts 
Table 4. Physical properties and NDF degradation characteristics of experimental diets

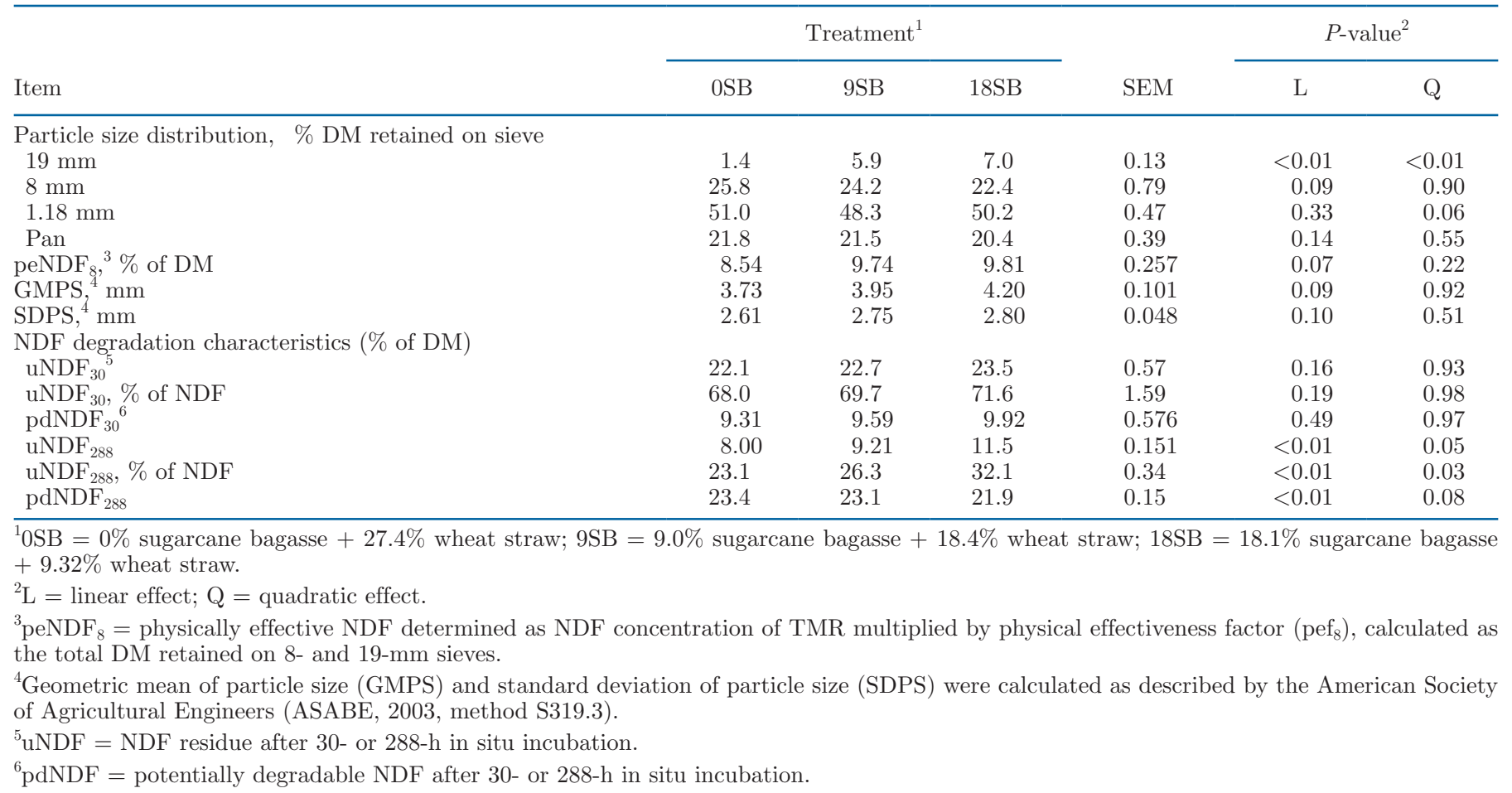

samples were dried at $60^{\circ} \mathrm{C}$ in a forced-air oven for 48 $\mathrm{h}$ and ground to pass a 1-mm sieve (Wiley mill, Arthur H. Thomas). All samples (duplicates) were analyzed for DM (AOAC International, 2002; method 925.40), CP (AOAC International, 2006, method 955.04), ash (AOAC International, 2006; method 942.05), ether extract (EE; AOAC International, 2006, method 920.39), starch (Zhu et al., 2016), and NDF (using heat-resistant $\alpha$-amylase and sodium sulfite) and ADF sequentially according to Van Soest et al. (1991) with the Ankom Fiber Analyzer system (A200 model, Ankom Technology, Macedon, NY). The ADL was determined using AOAC International (2006) method 973.18, modified to use a 1.0-g sample in Ankom F57 bags (Ankom Technology). Nonfiber carbohydrates were calculated as $\mathrm{NFC}=\mathrm{OM}-(\mathrm{NDF}+\mathrm{CP}+\mathrm{EE})$.

During the sampling period, forages, TMR, and individual refusals of each cow were sampled for particle size separation. All samples were frozen immediately at $-20^{\circ} \mathrm{C}$ until subsequent analysis. After thawing, particle size distributions of representative subsamples were determined (in triplicate) on an as-fed basis using the Penn State Particle Separator (PSPS; Nasco, Fort Atkinson, WI) equipped with 3 sieves (19, 8, and 1.18 $\mathrm{mm})$. After thawing, the DM retained on each sieve of the PSPS was determined by oven drying at $60^{\circ} \mathrm{C}$ for 48 $\mathrm{h}$ and the physical effectiveness factor (pef) was deter- mined as the proportion of DM retained on 2 sieves (8 $+19 \mathrm{~mm}$, pef ${ }_{8}$; Lammers et al., 1996) and on 3 sieves $\left(1.18+8+19 \mathrm{~mm}, \mathbf{p e f}_{1.18}\right.$; Kononoff et al., 2003) of the PSPS. The peNDF 8 and $\mathrm{peNDF}_{1.18}$ concentrations were calculated by multiplying the NDF concentration of the feed (\% of DM) by pef 8 and pef $_{1.18}$, respectively. Actual intakes of peNDF were calculated based on peNDF concentration of TMR and orts (thereby accounting for sorting). The geometric mean of particle size (GMPS) was calculated according to the ASABE (2003; method S319.3) procedure. Physical properties of experimental diets are presented in Table 4.

\section{Digestibility and N Balance}

Fecal samples were collected approximately every 8 h from d 16 to 18 so that 9 samples were taken from each cow each period. The samples were composited by cow and analyzed for nutrient digestibility using acidinsoluble ash (AIA) as an internal marker (Van Keulen and Young, 1977). The calculation of DM digestibility was as follows: DM digestibility $(\%)=1-(\mathrm{A} / \mathrm{B}) \times$ 100 , where $\mathrm{A}$ and $\mathrm{B}$ were the AIA concentrations in the feed and feces, respectively. The nutrient digestibilities $(\mathrm{X})$ were calculated as $\mathrm{X}$ digestibility $(\%)=$ $[1-(\mathrm{A} / \mathrm{B}) \times(\mathrm{XB} / \mathrm{XA})] \times 100$, where $\mathrm{XA}$ and $\mathrm{XB}$ were the nutrient concentrations in the feed and feces, 
respectively. Intakes presented during the digestibility measurements account for chemical composition of both the TMR and orts.

The intake of $\mathrm{N}(\mathrm{g} / \mathrm{d})$ was calculated by multiplying DMI by the $\mathrm{N}$ concentration of the diet. Predicted urine $\mathrm{N}$, fecal $\mathrm{N}$ excretion, and $\mathrm{N}$ efficiency were calculated (Kohn et al., 2002) using the following equations:

$$
\begin{gathered}
\text { Predicted urine N }(\mathrm{g} / \mathrm{d})= \\
0.0283 \times \text { MUN }(\mathrm{mg} / \mathrm{dL}) \times \mathrm{BW}(\mathrm{kg}), \\
\text { Predicted fecal N }(\mathrm{g} / \mathrm{d})=\mathrm{N} \text { intake }(\mathrm{g} / \mathrm{d}) \\
-[\text { milk N }(\mathrm{g} / \mathrm{d})+\text { predicted urine } \mathrm{N}(\mathrm{g} / \mathrm{d})], \\
\text { Apparent N efficiency }(\%)= \\
{[\text { milk N }(\mathrm{g} / \mathrm{d}) / \mathrm{N} \text { intake }(\mathrm{g} / \mathrm{d})] \times 100 .}
\end{gathered}
$$

\section{Chewing Behavior and Sorting Activity}

Eating and ruminating behaviors were monitored visually by 8 trained observers ( 1 every 3 h) for 24 -h on d 20 of each period. Beforehand, the process and definition of each behavior were reviewed with the observers, and then they simultaneously recorded cow behaviors to ensure agreement among them. Activity of the cows was noted every $5 \mathrm{~min}$ and the behavior (i.e., eating, ruminating, idling) was assumed to persist for the entire $5 \mathrm{~min}$. The total time spent performing each behavioral activity over $24 \mathrm{~h}$ was then expressed in minutes. Eating was defined as muzzle in or over the feed trough with the cow chewing or swallowing. Meals were later calculated as the sum of consecutive eating activity for at least $5 \mathrm{~min}$, preceded and followed by at least 5 min without eating activity. Rumination was defined as regurgitation, chewing, and swallowing of a bolus. Rumination bouts were then calculated as a period of ruminating consecutive boluses, preceded and followed by at least $5 \mathrm{~min}$ without ruminating. Total chewing time was calculated as the sum of total eating and ruminating times, and eating, ruminating, and chewing activities per kilogram of DM, NDF, peNDF, and $\mathrm{uNDF}$ intake were calculated by dividing total chewing activity by the respective intake recorded on $\mathrm{d}$ 20 . The rate of eating and ruminating were calculated as total time spent eating and rumination per day divided by DMI on d 20, respectively (Beauchemin and Yang, 2005). During milking, the cows walked to and from the milking parlor (20-30 min per round-trip) and were considered not to be chewing (i.e., idle).

Sorting of particles was determined from the actual intake of each fraction compared with the predicted intake of the same fraction had the diet been consumed as formulated (Leonardi and Armentano, 2003). A sorting index score was calculated for each fraction as the percentage of actual intake compared with the predicted intake. Values equal to $100 \%$ indicated no sorting, whereas values $<100 \%$ indicated selective refusals (sorting against), and $>100 \%$ indicated preferential consumption (sorting for).

\section{Milk Yield and Components, BW, and BCS}

The cows were milked 3 times daily at 0800, 1600, and $1200 \mathrm{~h}$ in a herringbone milking parlor. Milk yields were recorded and sampled during the $5 \mathrm{~d}$ of the sampling period and samples were preserved with potassium dichromate and stored at $4^{\circ} \mathrm{C}$ pending analysis. Milk samples were submitted to Ideh Sazan Rojan Alvand Co. (Alborz, Iran) for fat, true protein, lactose, SNF, TS, MUN, nonesterified fatty acids, BHB, and fatty acid analyses using Fourier-transform mid-infrared spectroscopy of CombiScope FTIR 600 HP (Delta Instruments, Drachten, the Netherlands).

The yields of 3.5\% FCM, ECM, and milk energy were calculated according to the following NRC (2001) equations:

$$
\begin{aligned}
& 3.5 \% \mathrm{FCM}=0.432 \times \text { milk yield }+16.23 \times \text { fat yield } \\
& \begin{aligned}
\mathrm{ECM}=12.82 \times \text { fat yield }+7.13 \times \text { true protein yield } \\
\quad+0.323 \times \text { milk yield }
\end{aligned} \\
& \text { Milk } \mathrm{NE}_{\mathrm{L}}(\mathrm{Mcal} / \mathrm{kg})=0.0929 \times \text { fat } \%+0.0547 \\
& \quad \times \text { true protein } \%+0.0395 \times \text { lactose } \%
\end{aligned}
$$

Daily secretion of milk energy (Mcal/d) was computed as milk $\mathrm{NE}_{\mathrm{L}} \times$ milk yield. Feed efficiency was calculated as kilograms of ECM per kilogram of DMI.

The BW of each cow was measured at the start and end of each period, after the morning milking. Body condition was scored by 2 experienced evaluators using a 5 -point scale where $1=$ emaciated and $5=$ obese at the beginning and end of each experimental period.

\section{Ruminal $\mathrm{pH}$ and Fermentation}

On the last day of each experimental period, approximately $4 \mathrm{~h}$ after the morning feeding, ruminal fluid (approximately $3 \mathrm{~mL}$ ) was sampled from the ventral sac via rumenocentesis, the technique developed by Nordlund and Garrett (1994). The $\mathrm{pH}$ was measured immediately, using a portable digital $\mathrm{pH}$ meter (HI 8318, Hanna Instruments, Cluj-Napoca, Romania) and 
the samples were immediately frozen at $-8^{\circ} \mathrm{C}$. Before freezing, a subsample of ruminal fluid was acidified with $200 \mu \mathrm{L}$ of $25 \%$ metaphosphoric acid per each $\mathrm{mL}$ of ruminal fluid. The ruminal fluid samples were thawed and analyzed for $\mathrm{NH}_{3}-\mathrm{N}$ by the colorimetric phenolhypochlorite method (Broderick and Kang, 1980). For VFA analysis, samples were thawed and centrifuged at $10,000 \times g$ at $4^{\circ} \mathrm{C}$ for 20 min and analyzed using $\mathrm{GC}$ $(0.25 \times 0.32,0.3 \mu \mathrm{m}$ i.d. fused silica capillary, model no. CP-9002 Vulcanusweg 259 a.m., Chrompack, Delft, the Netherlands), as described by Bal et al. (2000).

\section{Statistical Analyses}

Data were analyzed as a replicated $3 \times 3$ Latin square design using Proc Mixed of SAS (version 9.0, SAS Institute Inc., Cary, NC). Square, period within square, and treatment were considered as fixed effects in the model, whereas cow within square was included as a random effect. Normality of distribution and homogeneity of variance for the residuals were tested using PROC UNIVARIATE. Values are reported as least squares means. Polynomial orthogonal contrasts were used to test linear and quadratic responses. Significance was declared at $P \leq 0.05$, and tendencies were noted if 0.05 $<P \leq 0.10$.

\section{RESULTS}

\section{Forages and Diets}

Although a statistical analysis was not performed because the crop byproducts were from a single source, SB had numerically greater OM (94.1 vs. $85.1 \%$ of DM), $\mathrm{NDF}$ (86.2 vs. $76.4 \%$ of $\mathrm{DM}$ ), $\mathrm{ADF}$ (62.9 vs. $45.2 \%$ of $\mathrm{DM}$ ), and ADL (19.9 vs. $10.3 \%$ of DM) concentrations, and less CP (2.63 vs. $3.72 \%$ of DM) and AIA (2.69 vs. $6.98 \%$ of DM) concentrations than WS (Table 1). The $\mathrm{NFC}$ and predicted $\mathrm{NE}_{\mathrm{L}}$ concentrations were approximately similar between SB and WS.

Physical properties and NDF characteristics of the roughage sources are presented in Table 2. The SB had greater $\operatorname{peNDF}_{8}$ (63.2 vs. $40.6 \%$ of $\left.\mathrm{DM}\right), \mathrm{peNDF}_{1.18}$ ( 83.5 vs. $72.1 \%$ of DM), GMPS (10.7 vs. $6.6 \mathrm{~mm}$ ), $\mathrm{uNDF}_{30}(65.1$ vs. $54.2 \%$ of DM and 75.6 vs. $70.8 \%$ of $\mathrm{NDF}$ ), $\mathrm{uNDF}_{72}$ (45.8 vs. $35.3 \%$ of DM and 53.2 vs. $46.2 \%$ of NDF), and $\mathrm{uNDF}_{288}$ (35.5 vs. $21.2 \%$ of $\mathrm{DM}$ and 41.4 vs. $27.7 \%$ of NDF) than WS. Consequently, SB contained less $\mathrm{pdNDF}_{288}$ (50.7 vs. $55.2 \%$ of DM) compared with WS. A greater proportion of particles was retained on the 19 -mm sieve $(24.9$ vs. $2.6 \%, P<$ 0.01) for SB compared with WS, and correspondingly a smaller proportion of particles was retained on the 1.18 -mm sieve ( 23.6 vs. $41.2 \%, P<0.01)$ and pan $(3.1$ vs. $5.7 \%, P=0.01)$ for SB compared with WS. The proportion of particles retained on the 8 -mm sieve was not different between roughages $(P=0.16)$.

With increasing SB proportion in the diet, $\mathrm{uNDF}_{288}$ as a percentage of TMR DM and NDF increased linearly $(P<0.01$; Table 4$)$. The proportion of particles retained on the $19-\mathrm{mm}$ sieve $(P<0.01)$ increased linearly as inclusion of SB in the diets increased. Furthermore, $\operatorname{peNDF}_{8}(P=0.07)$ and GMPS $(P=0.09)$ tended to increase linearly as SB replaced WS in the diets.

\section{Intake, Sorting Activity, and Apparent Digestibility}

The intake of DM on the 1.18-mm sieve was not different among treatments (Table 5). However, DMI of material on the 19-mm sieve increased and that on the 8 -mm sieve decreased linearly $(P<0.01)$ with increasing SB level. The sorting index for particles retained on the 19-mm sieve decreased as WS was replaced with SB $(P<0.01)$, indicating sorting against the long particles provided by SB. In contrast, there was increased preference for small particles retained on the $1.18-\mathrm{mm}$ sieve as proportion of SB in the diet increased $(P<0.01)$.

Average DM $(26.53 \mathrm{~kg} / \mathrm{d})$, EE $(1.62 \mathrm{~kg} / \mathrm{d})$, starch $(7.21 \mathrm{~kg} / \mathrm{d})$, and NDF $(8.58 \mathrm{~kg} / \mathrm{d})$ intake did not differ among the treatments (Table 6). However, OM $(P<$ $0.01)$ and $\mathrm{CP}(P=0.03)$ intake decreased and $\mathrm{ADF}$ $(P=0.03)$ intake increased linearly as $\mathrm{SB}$ inclusion in the diets increased. The $\mathrm{uNDF}_{288}$ intakes increased linearly $(P<0.01)$ as WS was replaced with SB. The total-tract digestibility of $\mathrm{OM}, \mathrm{CP}$, starch, and NDF decreased linearly $(P<0.01)$ as SB replaced WS.

\section{Milk Yield and Components and Feed Efficiency}

Average milk (37.0 kg/d), 3.5\% FCM $(39.5 \mathrm{~kg} / \mathrm{d})$, and ECM $(38.2 \mathrm{~kg} / \mathrm{d})$ yield did not differ among the treatments (Table 7). Moreover, the treatments had no effect on milk composition including fat $(3.89 \%)$, true protein $(2.90 \%)$, and lactose $(4.39 \%)$ concentrations. Feed efficiency was constant among treatments, and cows produced an average of 1.40 and $1.44 \mathrm{~kg}$ of raw milk or ECM per $\mathrm{kg}$ of DMI, respectively. The BW, BCS, and backfat thickness were not affected by treatments. Milk energy (Mcal $/ \mathrm{kg}$ ), milk energy excretion (Mcal/d), and milk energy excretion per kilogram of DMI were not different among treatments.

Milk fatty acid profiles were not different among treatments (Supplemental Table S1; https://doi.org/ 10.3168/jds.2020-18499). Dietary treatment had no effects on milk concentrations of nonesterified fatty acids, BHB, and MUN, which averaged $477 \mathrm{mEq} / \mathrm{dL}, 0.11$ $\mathrm{mmol} / \mathrm{L}$, and $14.3 \mathrm{mg} / \mathrm{dL}$, respectively. 
Table 5. Effects of substitution of sugarcane bagasse for wheat straw on sorting activity and intake of particles (DM basis) of mid-lactation Holstein dairy cows $(\mathrm{n}=9)$

\begin{tabular}{|c|c|c|c|c|c|c|}
\hline \multirow[b]{2}{*}{ Item } & \multicolumn{3}{|c|}{ Treatment $^{1}$} & \multirow[b]{2}{*}{ SEM } & \multicolumn{2}{|c|}{$P$-value ${ }^{2}$} \\
\hline & 0SB & $9 \mathrm{SB}$ & $18 \mathrm{SB}$ & & $\mathrm{L}$ & $\mathrm{Q}$ \\
\hline \multicolumn{7}{|l|}{ Intake, kg/d } \\
\hline $19 \mathrm{~mm}$ & 0.35 & 1.24 & 1.38 & 0.061 & $<0.01$ & $<0.01$ \\
\hline $8 \mathrm{~mm}$ & 6.86 & 6.42 & 5.83 & 0.121 & $<0.01$ & 0.54 \\
\hline $1.18 \mathrm{~mm}$ & 13.8 & 13.1 & 13.5 & 0.22 & 0.32 & 0.04 \\
\hline Pan & 5.76 & 5.79 & 5.49 & 0.091 & 0.06 & 0.18 \\
\hline $\operatorname{peNDF}_{8},{ }^{3} \%$ of DM & 2.16 & 2.35 & 2.26 & 0.039 & 0.22 & 0.06 \\
\hline \multicolumn{7}{|l|}{ Sorting index, $\%$} \\
\hline $19 \mathrm{~mm}$ & 100.0 & 77.1 & 72.2 & 4.05 & $<0.01$ & 0.05 \\
\hline $8 \mathrm{~mm}$ & 98.8 & 99.8 & 99.9 & 0.64 & 0.33 & 0.53 \\
\hline $1.18 \mathrm{~mm}$ & 101.0 & 102.0 & 104.0 & 0.31 & $<0.01$ & 0.90 \\
\hline Pan & 100.0 & 102.1 & 101.0 & 0.94 & 0.55 & 0.27 \\
\hline
\end{tabular}

\section{Chewing Behavior}

Increasing SB in the diets linearly increased rumination $(P=0.01)$ and total chewing $(P=0.02)$ time, whereas eating time $(P=0.64)$ was not affected (Table $8)$. Eating time as minutes per kilogram of $\mathrm{uNDF}_{288}$ $(P<0.01)$ decreased linearly as SB inclusion in the diets increased. The rumination time as minutes per kilogram of $\mathrm{DM}, \mathrm{NDF}$, and $\mathrm{peNDF}_{8}$ intake increased linearly as SB inclusion in the diets increased. Total chewing time increased linearly when expressed per day or as minutes per kilogram of DM, NDF, $\mathrm{uNDF}_{288}$, and $\mathrm{peNDF}_{8}$ intake as SB inclusion in the diets increased.

Meal patterns were not affected by dietary treatments (Table 9), except for meal size of $\mathrm{uNDF}_{288}$, which linearly increased $(P<0.01)$ with increasing SB inclusion in the diets. Rumination bout length (min; $P=$ $0.01)$ and rate $(\mathrm{g}$ of $\mathrm{DM} / \mathrm{min}, P<0.01)$ increased and decreased linearly, respectively, with increasing the SB inclusion in the diets. The time between rumination

Table 6. Effects of substitution of sugarcane bagasse for wheat straw on nutrient intake and digestibility of mid-lactation Holstein dairy cows $(\mathrm{n}=9)$

\begin{tabular}{|c|c|c|c|c|c|c|}
\hline \multirow[b]{2}{*}{ Item } & \multicolumn{3}{|c|}{ Treatment $^{1}$} & \multirow[b]{2}{*}{ SEM } & \multicolumn{2}{|c|}{$P$-value ${ }^{2}$} \\
\hline & 0SB & $9 \mathrm{SB}$ & $18 \mathrm{SB}$ & & $\mathrm{L}$ & Q \\
\hline \multicolumn{7}{|l|}{ Intake, $\mathrm{kg} / \mathrm{d}$} \\
\hline DM & 26.88 & 26.52 & 26.19 & 0.437 & 0.30 & 0.98 \\
\hline $\mathrm{OM}$ & 24.94 & 24.77 & 24.45 & 0.030 & $<0.01$ & 0.17 \\
\hline Ether extract & 1.56 & 1.68 & 1.63 & 0.033 & 0.24 & 0.16 \\
\hline $\mathrm{CP}$ & 4.52 & 4.37 & 4.24 & 0.035 & 0.03 & 0.88 \\
\hline Starch & 7.19 & 7.19 & 7.26 & 0.069 & 0.57 & 0.71 \\
\hline NDF & 8.44 & 8.59 & 8.72 & 0.131 & 0.28 & 0.96 \\
\hline $\mathrm{uNDF}_{30}{ }^{3}$ & 5.94 & 6.04 & 6.15 & 0.151 & 0.38 & 0.98 \\
\hline $\mathrm{uNDF}_{288}{ }^{3}$ & 2.15 & 2.45 & 3.01 & 0.041 & $<0.01$ & 0.06 \\
\hline $\operatorname{pdNDF}_{30} 4$ & 2.51 & 2.55 & 2.60 & 0.152 & 0.68 & 0.99 \\
\hline $\operatorname{pdNDF}_{288}{ }^{4}$ & 6.30 & 6.14 & 5.74 & 0.041 & $<0.01$ & 0.07 \\
\hline $\mathrm{ADF}$ & 4.26 & 4.38 & 5.13 & 0.110 & 0.03 & 0.14 \\
\hline \multicolumn{7}{|c|}{ Total-tract digestibility, $\%$} \\
\hline $\mathrm{OM}$ & 84.6 & 80.1 & 76.4 & 1.11 & $<0.01$ & 0.73 \\
\hline $\mathrm{CP}$ & 85.1 & 82.3 & 78.3 & 1.17 & $<0.01$ & 0.60 \\
\hline Starch & 97.1 & 96.4 & 95.8 & 0.23 & $<0.01$ & 0.99 \\
\hline NDF & 70.1 & 63.5 & 54.4 & 2.17 & $<0.01$ & 0.66 \\
\hline
\end{tabular}

${ }^{1} 0 \mathrm{SB}=0 \%$ sugarcane bagasse $+27.4 \%$ wheat straw; $9 \mathrm{SB}=9.0 \%$ sugarcane bagasse $+18.4 \%$ wheat straw; $18 \mathrm{SB}=18.1 \%$ sugarcane bagasse $+9.32 \%$ wheat straw.

${ }^{2} \mathrm{~L}=$ linear effect; $\mathrm{Q}=$ quadratic effect.

${ }^{3} \mathrm{uNDF}=$ NDF residue after $30-$ or 288 -h in situ incubation.

${ }^{4} \mathrm{pdNDF}=$ potentially degradable NDF after 30 - or 288 -h in situ incubation. 
Table 7. Effects of substitution of sugarcane bagasse for wheat straw on milk production and composition and feed efficiency of mid-lactation Holstein dairy cows $(\mathrm{n}=9)$

\begin{tabular}{|c|c|c|c|c|c|c|}
\hline \multirow[b]{2}{*}{ Item } & \multicolumn{3}{|c|}{ Treatment $^{1}$} & \multirow[b]{2}{*}{ SEM } & \multicolumn{2}{|c|}{$P$-value ${ }^{2}$} \\
\hline & 0SB & 9SB & $18 \mathrm{SB}$ & & $\mathrm{L}$ & Q \\
\hline \multicolumn{7}{|l|}{ Yield, kg/d } \\
\hline Milk & 36.6 & 37.5 & 37.1 & 1.25 & 0.51 & 0.37 \\
\hline FCM $3.5 \%$ & 39.2 & 40.2 & 39.1 & 1.60 & 0.93 & 0.35 \\
\hline ECM & 37.9 & 38.9 & 37.9 & 1.49 & 0.98 & 0.30 \\
\hline Fat & 1.44 & 1.47 & 1.42 & 0.071 & 0.73 & 0.43 \\
\hline True protein & 1.06 & 1.09 & 1.04 & 0.036 & 0.70 & 0.32 \\
\hline Lactose & 1.61 & 1.65 & 1.63 & 0.058 & 0.62 & 0.35 \\
\hline SNF & 2.95 & 3.03 & 2.98 & 0.104 & 0.62 & 0.28 \\
\hline TS & 4.39 & 4.51 & 4.40 & 0.171 & 0.90 & 0.26 \\
\hline Milk $\mathrm{NE}_{\mathrm{L}}$, Mcal $/ \mathrm{kg}$ & 0.70 & 0.70 & 0.69 & $<0.001$ & 0.28 & 0.62 \\
\hline Milk $\mathrm{NE}_{\mathrm{L}}$ excretion, Mcal/d & 25.6 & 26.2 & 25.5 & 1.03 & 0.92 & 0.30 \\
\hline Milk $\mathrm{NE}_{\mathrm{L}}$ excretion/DMI, Mcal/kg & 0.94 & 0.98 & 0.97 & 0.040 & 0.39 & 0.56 \\
\hline \multicolumn{7}{|l|}{ Milk composition, $\%$} \\
\hline Fat & 3.93 & 3.91 & 3.83 & 0.097 & 0.37 & 0.77 \\
\hline True protein & 2.90 & 2.90 & 2.90 & 0.032 & 0.84 & 0.85 \\
\hline Lactose & 4.39 & 4.39 & 4.38 & 0.051 & 0.52 & 0.82 \\
\hline SNF & 8.05 & 8.07 & 8.03 & 0.073 & 0.64 & 0.58 \\
\hline $\mathrm{TS}$ & 11.98 & 12.00 & 11.85 & 0.131 & 0.21 & 0.40 \\
\hline \multicolumn{7}{|l|}{ Efficiency, $\mathrm{kg} / \mathrm{kg}$} \\
\hline Milk/DMI & 1.36 & 1.41 & 1.43 & 0.049 & 0.24 & 0.75 \\
\hline ECM/DMI & 1.41 & 1.46 & 1.45 & 0.059 & 0.48 & 0.66 \\
\hline $\mathrm{BW}, \mathrm{kg}$ & 660 & 659 & 652 & 11.5 & 0.06 & 0.41 \\
\hline
\end{tabular}

${ }^{1} 0 \mathrm{SB}=0 \%$ sugarcane bagasse $+27.4 \%$ wheat straw; $9 \mathrm{SB}=9.0 \%$ sugarcane bagasse $+18.4 \%$ wheat straw; $18 \mathrm{SB}=18.1 \%$ sugarcane bagasse $+9.32 \%$ wheat straw.

${ }^{2} \mathrm{~L}=$ linear effect; $\mathrm{Q}=$ quadratic effect.

Table 8. Effects of substitution of sugarcane bagasse for wheat straw on chewing activity of mid-lactation Holstein dairy cows $(\mathrm{n}=9)$

\begin{tabular}{|c|c|c|c|c|c|c|}
\hline \multirow[b]{2}{*}{ Item $^{1}$} & \multicolumn{3}{|c|}{ Treatment $^{2}$} & \multirow[b]{2}{*}{ SEM } & \multicolumn{2}{|c|}{$P$-value ${ }^{3}$} \\
\hline & 0SB & 9SB & $18 \mathrm{SB}$ & & $\mathrm{L}$ & Q \\
\hline \multicolumn{7}{|l|}{ Eating } \\
\hline $\operatorname{Min} / \mathrm{d}$ & 283 & 298 & 290 & 22.3 & 0.64 & 0.52 \\
\hline $\mathrm{Min} / \mathrm{kg}$ of DM & 10.5 & 11.2 & 11.1 & 0.84 & 0.31 & 0.47 \\
\hline $\mathrm{Min} / \mathrm{kg}$ of NDF & 33.5 & 34.8 & 33.3 & 2.55 & 0.92 & 0.40 \\
\hline $\mathrm{Min} / \mathrm{kg}$ of $\mathrm{uNDF}_{288}$ & 132 & 122 & 96.3 & 9.04 & $<0.01$ & 0.20 \\
\hline $\mathrm{Min} / \mathrm{kg}$ of $\mathrm{peNDF}_{8}$ & 131 & 127 & 128 & 11.9 & 0.67 & 0.60 \\
\hline \multicolumn{7}{|l|}{ Rumination } \\
\hline $\operatorname{Min} / \mathrm{d}$ & 376 & 426 & 477 & 32.4 & 0.01 & 0.97 \\
\hline Min/kg of DM & 13.9 & 16.1 & 18.2 & 1.04 & $<0.01$ & 0.93 \\
\hline Min/kg of NDF & 44.5 & 49.8 & 54.7 & 3.17 & 0.01 & 0.89 \\
\hline $\mathrm{Min} / \mathrm{kg}$ of $\mathrm{uNDF}_{288}$ & 175 & 174 & 158 & 11.9 & 0.23 & 0.56 \\
\hline $\mathrm{Min} / \mathrm{kg}$ of $\mathrm{peNDF}_{8}$ & 174 & 181 & 211 & 12.6 & $<0.01$ & 0.26 \\
\hline \multicolumn{7}{|l|}{ Total chewing activity } \\
\hline $\operatorname{Min} / \mathrm{d}$ & 659 & 724 & 767 & 33.6 & 0.02 & 0.77 \\
\hline Min/kg of DM & 24.5 & 27.3 & 29.3 & 1.04 & $<0.01$ & 0.73 \\
\hline $\mathrm{Min} / \mathrm{kg}$ of $\mathrm{NDF}$ & 77.9 & 84.6 & 87.9 & 3.25 & 0.02 & 0.62 \\
\hline $\mathrm{Min} / \mathrm{kg}$ of $\mathrm{uNDF}_{288}$ & 306 & 295 & 255 & 12.5 & $<0.01$ & 0.31 \\
\hline $\mathrm{Min} / \mathrm{kg}$ of $\mathrm{peNDF}_{8}$ & 305 & 308 & 340 & 17.4 & 0.04 & 0.27 \\
\hline
\end{tabular}

${ }^{1} \mathrm{uNDF}_{288}=\mathrm{NDF}$ residue after 288 -h in situ incubation; peNDF $_{8}=$ physically effective NDF determined as NDF concentration (\% DM) of TMR multiplied by physical effectiveness factor, calculated as the total DM retained on 8 - and 19 -mm sieves.

${ }^{2} 0 \mathrm{SB}=0 \%$ sugarcane bagasse $+27.4 \%$ wheat straw; $9 \mathrm{SB}=9.0 \%$ sugarcane bagasse $+18.4 \%$ wheat straw; $18 \mathrm{SB}=18.1 \%$ sugarcane bagasse $+9.32 \%$ wheat straw.

${ }^{3} \mathrm{~L}=$ linear effect; $\mathrm{Q}=$ quadratic effect. 
Table 9. Effects of substitution of sugarcane bagasse for wheat straw on meal patterns of mid-lactation Holstein dairy cows $(\mathrm{n}=9)$

\begin{tabular}{|c|c|c|c|c|c|c|}
\hline \multirow[b]{2}{*}{ Item $^{1}$} & \multicolumn{3}{|c|}{ Treatment $^{2}$} & \multirow[b]{2}{*}{ SEM } & \multicolumn{2}{|c|}{$P$-value ${ }^{3}$} \\
\hline & 0SB & $9 \mathrm{SB}$ & 18SB & & $\mathrm{L}$ & $\mathrm{Q}$ \\
\hline \multicolumn{7}{|l|}{ Eating } \\
\hline Meals/d & 14.1 & 14.4 & 14.1 & 0.70 & 0.60 & 0.20 \\
\hline Min/meal & 19.7 & 20.5 & 20.4 & 1.96 & 0.72 & 0.41 \\
\hline Time between meals, min & 123 & 130 & 134 & 11.8 & 0.51 & 0.97 \\
\hline Rate, $\mathrm{g}$ of $\mathrm{DM} / \mathrm{min}$ & 95.5 & 90.0 & 90.0 & 0.01 & 0.20 & 0.78 \\
\hline \multicolumn{7}{|l|}{ Meal size } \\
\hline $\mathrm{kg}$ of DM & 1.85 & 1.85 & 1.82 & 0.179 & 0.58 & 0.73 \\
\hline $\mathrm{kg}$ of NDF & 0.58 & 0.60 & 0.61 & 0.061 & 0.14 & 0.80 \\
\hline $\mathrm{kg}$ of $\mathrm{uNDF}_{288}$ & 0.15 & 0.17 & 0.21 & 0.021 & $<0.01$ & 0.39 \\
\hline $\mathrm{kg}$ of $\mathrm{peNDF}_{8}$ & 0.15 & 0.16 & 0.16 & 0.021 & 0.15 & 0.20 \\
\hline \multicolumn{7}{|l|}{ Rumination } \\
\hline Bouts/d & 12.7 & 12.8 & 12.7 & 0.53 & 0.51 & 0.47 \\
\hline Min/bout & 29.6 & 33.2 & 37.7 & 2.81 & 0.01 & 0.87 \\
\hline Time between bouts, min & 122.4 & 93.5 & 82.4 & 17.22 & 0.08 & 0.64 \\
\hline Rate, $\mathrm{g}$ of $\mathrm{DM} / \mathrm{min}$ & 72.0 & 62.0 & 55.0 & 0.01 & $<0.01$ & 0.69 \\
\hline
\end{tabular}

${ }^{1} \mathrm{uNDF}_{288}=\mathrm{NDF}$ residue after 288 -h in situ incubation; peNDF $_{8}=$ physically effective NDF determined as NDF concentration (\% DM) of TMR multiplied by physical effectiveness factor, calculated as the total DM retained on 8 - and 19 -mm sieves.

${ }^{2} 0 \mathrm{SB}=0 \%$ sugarcane bagasse $+27.4 \%$ wheat straw; $9 \mathrm{SB}=9.0 \%$ sugarcane bagasse $+18.4 \%$ wheat straw; $18 \mathrm{SB}=18.1 \%$ sugarcane bagasse $+9.32 \%$ wheat straw.

${ }^{3} \mathrm{~L}=$ linear effect; $\mathrm{Q}=$ quadratic effect.

bouts tended to decrease linearly with inclusion of SB $(P=0.08)$.

\section{Ruminal pH, Fermentation, and N Metabolism}

The average ruminal $\mathrm{pH}$ value for cows fed 0SB, 9SB, and $18 \mathrm{SB}$ diets was $6.68,6.50$, and 6.10 , respectively, and it decreased linearly as WS was replaced by SB $\left(P<0.01\right.$; Table 10). No differences in ruminal $\mathrm{NH}_{3}$ concentration occurred among treatments. Total VFA concentration $(P=0.02)$ and propionate proportion $(P<0.01)$ increased linearly as SB inclusion in the diets increased, whereas acetate proportion and acetate: propionate ratio decreased linearly $(P<0.01)$.
The $\mathrm{N}$ intake $(\mathrm{g} / \mathrm{d})$ tended to decrease linearly with inclusion of SB $(P=0.07)$, whereas milk $\mathrm{N}$ and predicted urinary $\mathrm{N}$ were not affected by diet (Supplemental Table S2; https://doi.org/10.3168/jds.2020-18499). Also, predicted fecal N $(P=0.02)$ decreased linearly and apparent $\mathrm{N}$ efficiency $(P=0.03)$ increased linearly as WS was replaced by SB.

\section{DISCUSSION}

The study examined the effects of replacing WS with $\mathrm{SB}$ in the diet of mid-lactation dairy cows on performance, digestibility, chewing activity, and ruminal fermentation. The basal diet fed to the cows was ex-

Table 10. Effects of substitution of sugarcane bagasse for wheat straw on ruminal fermentation of midlactation Holstein dairy cows $(\mathrm{n}=9)$

\begin{tabular}{|c|c|c|c|c|c|c|}
\hline \multirow[b]{2}{*}{ Item } & \multicolumn{3}{|c|}{ Treatment $^{1}$} & \multirow[b]{2}{*}{ SEM } & \multicolumn{2}{|c|}{$P$-value ${ }^{2}$} \\
\hline & 0SB & 9SB & $18 \mathrm{SB}$ & & $\mathrm{L}$ & $\mathrm{Q}$ \\
\hline $\mathrm{pH}$ & 6.68 & 6.50 & 6.10 & 0.077 & $<0.01$ & 0.31 \\
\hline $\mathrm{NH}_{3}, \mathrm{mg} / \mathrm{dL}$ & 10.5 & 10.5 & 9.7 & 1.66 & 0.51 & 0.71 \\
\hline Total VFA, mmol/L & 111 & 115 & 127 & 3.9 & 0.02 & 0.34 \\
\hline Acetate, mol/100 mol & 66.0 & 64.1 & 63.4 & 0.60 & $<0.01$ & 0.16 \\
\hline Propionate, $\mathrm{mol} / 100 \mathrm{~mol}$ & 18.4 & 19.9 & 21.1 & 0.49 & $<0.01$ & 0.68 \\
\hline Butyrate, mol/100 mol & 11.4 & 11.6 & 11.0 & 0.44 & 0.55 & 0.43 \\
\hline Isobutyrate, $\mathrm{mol} / 100 \mathrm{~mol}$ & 0.82 & 0.83 & 0.86 & 0.059 & 0.48 & 0.89 \\
\hline Valerate, $\mathrm{mol} / 100 \mathrm{~mol}$ & 1.15 & 1.12 & 1.29 & 0.088 & 0.08 & 0.92 \\
\hline Isovalerate, $\mathrm{mol} / 100 \mathrm{~mol}$ & 2.32 & 2.23 & 2.39 & 0.160 & 0.54 & 0.23 \\
\hline Acetate:propionate & 3.61 & 3.26 & 3.02 & 0.111 & $<0.01$ & 0.60 \\
\hline
\end{tabular}

${ }^{1} 0 \mathrm{SB}=0 \%$ sugarcane bagasse $+27.4 \%$ wheat straw; $9 \mathrm{SB}=9.0 \%$ sugarcane bagasse $+18.4 \%$ wheat straw; $18 \mathrm{SB}=18.1 \%$ sugarcane bagasse $+9.32 \%$ wheat straw.

${ }^{2} \mathrm{~L}=$ linear effect; $\mathrm{Q}=$ quadratic effect. 
ceptionally high in concentrate $(73 \%$ of $\mathrm{DM})$ to provide the $\mathrm{NE}_{\mathrm{L}}$ required, given the relative low quality of the roughage sources used in the study. As a result, average ECM yield of the cows $(38.2 \mathrm{~kg} / \mathrm{d})$ during the study was relatively high. The Latin square design accounted for cow and period effects while individually housing the cows allowed for measurements of individual animal responses to changes in dietary roughage source and proportion. However, the results should be interpreted in context of the conditions employed, as the relatively short (21 d) length of the periods in the Latin square design and limited number of cows per treatment $(\mathrm{n}=$ 9) are limitations of the study. In particular, the milk production results need to be confirmed over a longer feeding period using a greater number of cows.

The chemical compostion of WS was typical of wheat grown in Iran (Kahyani et al., 2019a,b), but its nutritive value was poor compared with other research (Eastridge et al., 2009). The chemical composition of SB was similar to that reported by others (Ramli et al., 2005; de Almeida et al., 2018; Freitas et al., 2018). The greater NDF, ADF, and ADL concentrations of SB compared with WS resulted in more fibrous diets when WS was replaced by SB. Diets containing SB also had greater proportion of long particles (retained on the 19-mm sieve), peNDF$_{8}$, and GMPS, indicating that SB was a superior source of physical fiber compared with WS. However, SB was also less degradable than WS; it had greater uNDF concentrations when measured at 30 and $288 \mathrm{~h}$ compared with WS. Hence, the pdNDF concentration of SB was less than that of WS. Therefore, the dietary concentration of $\mathrm{uNDF}_{288}$ linearly increased as the level of SB increased in the diets. The $\mathrm{uNDF}_{288}$ in SB represented nearly $41 \%$ of NDF compared with $28 \%$ for WS, consistent with a previous study by de Almeida et al. (2018). The SB also had substantially greater ADL concentration than WS (19.9 vs. $10.3 \%$ of DM). The greater UNDF and ADL concentrations of SB resulted in a decrease in total-tract digestibility of nutrients when SB replaced WS in the diets. Compared with other forages, total-tract NDF digestibility of SB is low ( $<35 \%$; Oliveira et al., 2011) due to its high proportion of uNDF ( $\sim 50 \%$ of NDF) and lesser pdNDF concentration (Daniel et al., 2014).

The concentrations of fiber, lignin, ash, and fat in feeds have a direct effect on $\mathrm{NE}_{\mathrm{L}}$ concentration; fiber (ADF and NDF) and lignin concentrations are negatively related to $\mathrm{NE}_{\mathrm{L}}$ because fiber, on average, is less digestible than nonfiber and lignin is not digestible (Weiss, 1998). Furthermore, ash contributes no energy and therefore dilutes digestible OM (Weiss, 1998). In the current experiment, the ash concentration of WS was 3 times that of SB, but the fiber (ADF and NDF) and lignin concentrations of SB were greater than those in WS. Consequently, the digestible energy concentrations of WS and SB were similar.

Although substituting WS with SB increased the particle size and peNDF concentration of the TMR, it also increased the sorting against $>19$-mm particles. It was previously observed that cows sort against longer particles to a greater degree when low-digestibility forage is offered (Suarez-Mena et al., 2013; Miller-Cushon and DeVries, 2017). Hence, decreasing the particle size of low-quality forage can help minimize sorting against longer particles (Suarez-Mena et al., 2013; Coon et al., 2018). Because the cows in the current experiment sorted against long particles, $\mathrm{peNDF}_{8}$ intake was only marginally increased with incorporation of SB in diets, even though it was a better source of physical fiber than WS. Increased sorting was surprisingly not accompanied by an increase in eating time or a change in meal characteristics. Consequently, more kilograms of $\mathrm{uNDF}_{288}$ were consumed per meal with an increase in $\mathrm{SB}$ in diets.

It was expected that $\mathrm{SB}$ would limit feed intake compared with WS because of its greater NDF concentration and potential filling effect. It is well documented that DMI of ruminants is limited by physical distension of the gastrointestinal tract (de Almeida et al., 2018); however, that was not the case in the present study as DMI was not affected by substituting WS with SB. Similar pdNDF ${ }_{30}$ concentrations, despite lesser pdNDF ${ }_{288}$ concentrations, of SB compared with WS likely accounted for the lack of differences in DMI among diets. Grant and Cotanch (2012) reported that the filling effect of the diet could be related to the amount and rate of degradation of pdNDF. Wells (2016) reported that DMI was inversely related to hay $\mathrm{uNDF}_{30}$ concentration.

A high level of $\mathrm{uNDF}_{288}$ reduces the amount of $\mathrm{OM}$ available for degradation in the rumen, and therefore is associated with lesser total-tract digestibility of DM and NDF (Freitas et al., 2018). Other studies have similarly observed a decrease in total-tract digestibility with incorporation of SB in diets (Corrêa et al., 2003; de Almeida et al., 2018; Freitas et al., 2018). The $\mathrm{uNDF}_{288}$ was greater in SB than WS, and Ahvenjärvi et al. (2006) and Lopes et al. (2015b) indicated that $\mathrm{uNDF}_{288}$ decreases total-tract digestibility. In the current experiment, inclusion of SB in diets increased $\mathrm{uNDF}_{288}$ and decreased $\mathrm{pdNDF}_{288}$ concentrations in a linear manner. Moreover, SB had greater concentration of ADL, which would also contribute to lowering digestibility of DM and NDF in the gastrointestinal tract (Grabber, 2005; de Almeida et al., 2018).

Despite a decrease in diet total-tract apparent digestibility with increasing levels of SB added to diets, milk yield was not affected. All diets had similar amount of 
$\mathrm{uNDF}_{30}\left(22.7 \%\right.$ of DM) and $\mathrm{pdNDF}_{30}(9.6 \%$ of DM $)$, even though concentration of $\mathrm{uNDF}_{288}$ was increased with added SB. Consistent with our results, Sá Neto et al. (2014) compared a corn silage-based diet with a SB silage-based diet and reported similar DMI, milk yield, and milk composition in late-lactation dairy cattle. However, others reported that the DMI and milk production decreased linearly with incorporation of SB in diets (Corrêa et al., 2003; Freitas et al., 2018; de Almeida et al., 2018). In those experiments, SB replaced a higher quality forage (corn silage: Corrêa et al., 2003; spineless cactus: de Almeida et al., 2018; Freitas et al., 2018) unlike in our study where SB replaced WS. In addition, those studies used a greater proportion of SB in the diets (45\% of DM: Corrêa et al., 2003; 30-54\% of DM: Freitas et al., 2018; 45-60\% of DM: de Almeida et al., 2018) in comparison with the present experiment (9-18\% of DM). Cotanch et al. (2012) suggested that the negative response of milk production to uNDF concentration of the diet depends on forage proportion, because milk production was not affected by the source of corn silage when cows were fed diets with low forage content but milk production increased with the use of brown midrib corn silage when cows were fed high-forage diets. In our experiment, roughage content of the diets was low $(28 \%)$ and WS was only partially replaced. Thus, the effects of incorporating SB in dairy cow diets on cow productivity may depend on stage of lactation and hence requirements for energy, inclusion rate of SB in the diets, as well as the digestibility of the ingredient replaced by SB. In the present study, the lack of negative effect of SB on milk production was attributed to the mid-lactation stage of the cows, the replacement of WS, another low-quality crop byproduct, with $\mathrm{SB}$ such that $\mathrm{pdNDF}_{30}$ was not affected, and the relatively low inclusion rate in the diet.

The linear increase in total chewing and rumination time with increasing proportion of SB is consistent with the greater peNDF $\mathrm{N}_{8}$ and $\mathrm{uNDF}_{288}$ concentrations of the $\mathrm{SB}$ diets. Chewing and rumination per $\mathrm{kg}$ of NDF and $\mathrm{peNDF}_{8}$ intake linearly increased with inclusion SB, as a result of greater physical effectiveness of SB fiber. Mertens (1997) and Pereira et al. (1999) indicated that total chewing time greater than $650 \mathrm{~min} / \mathrm{d}$ and $30 \mathrm{~min} /$ $\mathrm{kg}$ of DM are characteristic of high-forage-based diets. Total chewing time in the current experiment averaged $716 \mathrm{~min} / \mathrm{d}$ and $26 \mathrm{~min} / \mathrm{kg}$ of $\mathrm{DM}$, even though the diets contained only $28 \%$ roughage DM. This finding suggests that $\mathrm{uNDF}$ and $\mathrm{peNDF}_{8}$ levels are probably more important than forage level in maintaining rumen health and milk fat production of dairy cows.

Increased chewing time with inclusion of SB in diets was entirely due to longer rumination time, which manifested by longer rumination bouts and shorter intervals between bouts. The linear increase in rumination time per kilogram of DM and NDF indicated the greater need for particle size reduction of diets that included SB (Beauchemin et al., 2001), despite sorting against long particles. These results indicate that intake of $\mathrm{peNDF}_{8}$ (particle size) and $\mathrm{uNDF}_{288}$ (resistance to chewing) are the main contributing factors to rumination time. As DMI was similar among treatments, yet rumination time increased linearly with SB inclusion, rumination rate $(\mathrm{g}$ of $\mathrm{DM} / \mathrm{min}$ ) decreased with the increase of $\mathrm{SB}$ content. Rumination activity has a more significant influence on the reduction of feed particle size and salivary secretion than eating activity (Grant et al., 1990). In agreement with our results, Freitas et al. (2018) and de Almeida et al. (2018) reported a linear increase in rumination time with SB level in the diet, but a linear decrease in rumination rate. In general, the cows in the present experiment were able to maintain their feed intake and ultimately milk production by sorting more against the particles retained on the 19-mm sieve and ruminating more to process the greater intake of less degradable fiber. In contrast to our results, Corrêa et al. (2003) noted no difference in chewing behavior when SB silage replaced corn silage in dairy cow diets.

It was expected that cows fed SB would have greater ruminal $\mathrm{pH}$ than cows fed 0SB, because of increased rumination time due to greater intake of long particles and $\mathrm{uNDF}_{288}$. However, the opposite effect was observed with ruminal $\mathrm{pH}$ decreasing with increased incorporation of SB into diets. The decrease in $\mathrm{pH}$ was associated with an increase in molar proportion of propionate and decrease in molar proportion of acetate, indicative in a shift in ruminal fermentation toward nonstructural carbohydrates. This shift in fermentation is consistent with the greater NFC concentration of SB. Contrary to our results, ruminal $\mathrm{pH}$ was not different between cows fed corn or SB silages (Corrêa et al., 2003). Beauchemin and Yang (2005) demonstrated that increasing the peNDF concentration of diets increased chewing time, but increased chewing time did not necessarily increase ruminal $\mathrm{pH}$. They stated that in addition to peNDF, fermentable OM intake also affects ruminal $\mathrm{pH}$. Beauchemin (2000) reported poor relationship $\left(\mathrm{R}^{2}\right.$ $<0.13$ ) between ruminal $\mathrm{pH}$ and dietary fiber measured as NDF, forage NDF or peNDF. It can be concluded that greater dietary $\mathrm{uNDF}_{288}$ intake increased rumination time, but did not improve ruminal $\mathrm{pH}$.

The lesser CP concentration of SB diets, combined with similar DMI, tended to linearly decrease $\mathrm{N}$ intake as SB content of the diet increased. Lack of effect of lesser $\mathrm{N}$ intake on milk $\mathrm{N}$ concentration indicated increased efficiency of transfer of dietary $\mathrm{N}$ to milk $\mathrm{N}$ with SB inclusion in diets. Thus, the cows fed SB used $\mathrm{N}$ more efficiently with more $\mathrm{N}$ directed toward milk 
rather than feces. Sá Neto et al. (2014) reported that $\mathrm{N}$ efficiency was similar between cows fed corn or SB silages. In contrast to our results, Freitas et al. (2018) reported that $\mathrm{N}$ efficiency decreased linearly with the increase of SB inclusion from 30 to $54 \%$ of DM. According to the NRC (2001), a 591-kg cow producing $41 \mathrm{~kg}$ of milk containing $3.5 \%$ milk fat requires 0.405 $\mathrm{kg}$ of $\mathrm{CP}$ for maintainance and $3.44 \mathrm{~kg}$ of CP for milk production, with a total $\mathrm{CP}$ requirement of $3.84 \mathrm{~kg} / \mathrm{d}$. In the current experiment, cows on 0SB, 9SB, and $18 \mathrm{SB}$ treatments consumed $4.5,4.3$, and $4.2 \mathrm{~kg} / \mathrm{d}$ of $\mathrm{CP}$, respectively, with these $\mathrm{CP}$ intakes greater than the requirement (NRC, 2001). The decrease in CP intake combined with a decrease in $\mathrm{CP}$ digestibility with increased SB inclusion in the diets likely promoted $\mathrm{N}$ efficiency.

\section{CONCLUSIONS}

There was no difference in the $\mathrm{uNDF}_{30}$ concentration of diets containing increasing proportions of SB and decreasing proportions WS, but dietary $\mathrm{uNDF}_{288}$ and $\mathrm{peNDF}_{8}$ concentrations increased linearly with SB inclusion. Partial substitution of WS with SB reduced total-tract apparent digestibility but did not negatively affect DMI or lactational performance of mid-lactation Holstein dairy cows producing $37 \mathrm{~kg} / \mathrm{d}$ of milk. We conclude that SB is a good source of peNDF for cows fed high-concentrate diets. However, SB is less digestible than WS in the total tract; therefore, performance of dairy cows may decrease when fed diets containing SB that limit DMI.

\section{ACKNOWLEDGMENTS}

The study was funded by the Isfahan University of Technology (Isfahan, Iran). Appreciation is extended to staff at the Lavark farm and the research and teaching unit (Isfahan University of Technology, Isfahan, Iran), Mostafa Nazari and Farshad Andarzgoo. The authors have not stated any conflicts of interest.

\section{REFERENCES}

Ahvenjärvi, S., E. Joki-Tokola, A. Vanhatalo, S. Jaakkola, and P. Huhtanen. 2006. Effects of replacing grass silage with barley silage in dairy cow diets. J. Dairy Sci. 89:1678-1687. https://doi.org/10 $.3168 /$ jds.S0022-0302(06)72235-4.

AOAC International. 2002. Official Methods of Analysis. 17th ed. 1st rev. AOAC Int., Gaithersburg, MD.

AOAC International. 2006. Official Methods of Analysis. 18th ed. AOAC International, Arlington, VA.

ASABE. 2003. Methods of determining and expressing fineness of feed materials by sieving. Standard no. S319.3. Pages 202-205. American Society of Agricultural and Biological Engineers, St. Joseph, MI.
Bal, M. A., R. D. Shaver, A. G. Jirovec, K. J. Shinners, and J. G. Coors. 2000. Crop processing and chop length of corn silage: Effects on intake, digestion, and milk production by dairy cows. J. Dairy Sci. 83:1264-1273. https://doi.org/10.3168/jds.S0022 -0302(00)74993-9.

Beauchemin, K. A. 2000. Managing rumen fermentation in barley based diets: Balance between high production and acidosis. Adv. Dairy Technol. 12:109-125.

Beauchemin, K. A., and W. Yang. 2005. Effects of physically effective fiber on intake, chewing activity, and ruminal acidosis for dairy cows fed diets based on corn silage. J. Dairy Sci. 88:2117-2129. https://doi.org/10.3168/jds.S0022-0302(05)72888-5.

Beauchemin, K. A., W. Yang, and L. Rode. 2001. Effects of barley grain processing on the site and extent of digestion of beef feedlot finishing diets. J. Anim. Sci. 79:1925-1936. https://doi.org/10 $.2527 / 2001.7971925 x$.

Broderick, G., and J. Kang. 1980. Automated simultaneous determination of ammonia and total amino acids in ruminal fluid and in vitro media. J. Dairy Sci. 63:64-75.

Coon, R. E., T. F. Duffield, and T. J. DeVries. 2018. Effect of straw particle size on the behavior, health, and production of early lactation dairy cows. J. Dairy Sci. 101:6375-6387. https://doi.org/10 .3168/jds.2017-13920.

Corrêa, C. E. S., M. N. Pereira, S. G. Oliveira, and M. H. Ramos. 2003. Performance of Holstein cows fed sugarcane or corn silages of different grain texture. Sci. Agric. 60:621-629. https://doi.org/ 10.1590/S0103-90162003000400003.

Costa, D. A., C. L. Souza, E. O. Saliba, and J. C. Carneiro. 2015. Byproducts of sugar cane industry in ruminant nutrition. Int. J. Adv. Agric. Res. 3:1-9.

Cotanch, K. W., C. Kokko, H. M. Dann, J. W. Darrah, and R. J. Grant. 2012. Amount and digestibility of NDF affects rumen nutrient pool sizes and passage kinetics of dairy cows. J. Dairy Sci. 95(Suppl. 1):181.

Daniel, J. L. P., A. Capelesso, E. H. Cabezas-Garcia, M. Zopollatto, M. C. Santos, P. Huhtanen, and L. G. Nussio. 2014. Fibre digestion potential in sugarcane across the harvesting window. Grass Forage Sci. 69:176-181. https://doi.org/10.1111/gfs.12044.

de Almeida, G. A. P., M. de Andrade Ferreira, J. de Lima Silva, J. C. C. Chagas, A. S. Chaves Véras, L. J. A. de Barros, and G. L. P. de Almeida. 2018. Sugarcane bagasse as exclusive roughage for dairy cows in smallholder livestock system. Asian-australas. J. Anim. Sci. 31:379-385.

Eastridge, M. L., P. B. Bucci, and C. V. D. M. Ribeiro. 2009. Feeding equivalent concentrations of forage neutral detergent fiber from alfalfa hay, grass hay, wheat straw, and whole cottonseed in corn silage based diets to lactating cows. Anim. Feed Sci. Technol. 150:86-94. https://doi.org/10.1016/j.anifeedsci.2008.08.008.

Edmonson, A. J., I. J. Lean, L. D. Weaver, T. Farver, and G. Webster. 1989. A body condition scoring chart for Holstein dairy cows. J. Dairy Sci. 72:68-78. https://doi.org/10.3168/jds.S0022 $-0302(89) 79081-0$.

FAOSTAT. 2016. Food and Agriculture Data Centers, Crops Production. Food and Agriculture Organization of the United Nations, Rome, Italy. Accessed Jul. 7, 2016. www.fao.org/faostat/ en/\#data/QC.

Ferraretto, L. F., A. C. Fonseca, C. J. Sniffen, A. Formigoni, and R. D. Shaver. 2015. Effect of corn silage hybrids differing in starch and neutral detergent fiber digestibility on lactation performance and total-tract nutrient digestibility by dairy cows. J. Dairy Sci. 98:395-405. https://doi.org/10.3168/jds.2014-8232.

Freitas, W. R., M. de Andrade Ferreira, J. L. Silva, A. S. C. Véras, L. J. A. Barros, A. M. S. V. Alves, J. C. C. Chagas, T. D. Q. Siqueira, and G. A. P. de Almeida. 2018. Sugarcane bagasse as only roughage for crossbred lactating cows in semiarid regions. Pesq. Agropec. Bras. Brasília. 53:386-393.

Grabber, J. H. 2005. How do lignin composition, structure, and crosslinking affect degradability? A review of cell wall model studies. Crop Sci. 45:820-831. https://doi.org/10.2135/cropsci2004.0191. 
Grant, R., V. Colenbrander, and D. Mertens. 1990. Milk fat depression in dairy cows: Role of silage particle size. J. Dairy Sci. 73:18341842. https://doi.org/10.3168/jds.S0022-0302(90)78863-7.

Grant, R. J., and K. W. Cotanch. 2012. Higher forage diets: Dynamics of passage, digestion, and cow productive responses. Pages 45-57 in Proceedings Cornell Nutrition Conference for Feed Manufacturers. October 16-18, Syracuse, NY.

Iranian Council of Animal Care. 1995. Guide to the Care and Use of Experimental Animals. Vol. 1. Isfahan University of Technology, Isfahan, Iran.

Kahyani, A., G. R. Ghorbani, M. Alikhani, E. Ghasemi, A. Sadeghi-Sefidmazgi, K. A. Beauchemin, and S. M. Nasrollahi. 2019a. Performance of dairy cows fed diets with similar proportions of undigested neutral detergent fiber with wheat straw substituted for alfalfa hay, corn silage, or both. J. Dairy Sci. 102:10903-10915. https://doi.org/10.3168/jds.2019-16869.

Kahyani, A., G. R. Ghorbani, M. Alikhani, E. Ghasemi, A. SadeghiSefidmazgi, and S. M. Nasrollahi. 2019b. Adjusting for 30-hour undigested neutral detergent fiber in substitution of wheat straw and beet pulp for alfalfa hay and corn silage in the diet of highproducing cows. J. Dairy Sci. 102:7026-7037. https://doi.org/10 $.3168 /$ jds.2018-15740.

Kohn, R. A., K. F. Kalscheur, and E. Russek-Cohen. 2002. Evaluation of models to estimate urinary nitrogen and expected milk urea nitrogen. J. Dairy Sci. 85:227-233. https://doi.org/10.3168/ jds.S0022-0302(02)74071-X.

Kononoff, P. J., A. J. Heinrichs, and D. R. Buckmaster. 2003. Modification of the Penn State forage and total mixed ration particle separator and the effects of moisture content on its measurements. J. Dairy Sci. 86:1858-1863.

Krizsan, S. J., and P. Huhtanen. 2013. Effect of diet composition and incubation time on feed indigestible neutral detergent fiber concentration in dairy cows. J. Dairy Sci. 96:1715-1726. https://doi .org/10.3168/jds.2012-5752.

Lammers, B. P., D. R. Buckmaster, and A. J. Heinrichs. 1996. A simple method for the analysis of particle sizes of forages and total mixed rations. J. Dairy Sci. 79:922-928.

Leme, P. R., S. I. Silva, A. S. C. Pereira, S. M. Putrino, D. P. D Lanna, and J. C. M. N. Filho. 2003. Levels of sugarcane bagasse in diets with high concentrate for Nellore steers in feedlot. Rev. Bras. Zootec. 32:1786-1791. https://doi.org/10.1590/S1516 $-35982003000700029$

Leonardi, C., and L. E. Armentano. 2003. Effect of quantity, quality, and length of alfalfa hay on selective consumption by dairy cows. J. Dairy Sci. 86:557-564. https://doi.org/10.3168/jds.S0022 -0302(03)73634-0.

Lopes, F., D. E. Cook, and D. K. Combs. 2015b. Effects of varying dietary ratios of corn silage to alfalfa silage on digestion of neutral detergent fiber in lactating dairy cows. J. Dairy Sci. 98:6291-6303. https://doi.org/10.3168/jds.2014-8662.

Lopes, F., K. Ruh, and D. K. Combs. 2015a. Validation of an approach to predict total-tract fiber digestibility using a standardized in vitro technique for different diets fed to high-producing dairy cows. J. Dairy Sci. 98:2596-2602. https://doi.org/10.3168/ jds.2014-8665.

Mertens, D. R. 1997. Creating a system for meeting the fiber requirements of dairy cows. J. Dairy Sci. 80:1463-1481. https://doi.org/ 10.3168/jds.S0022-0302(97)76075-2.

Miller-Cushon, E. K., and T. J. DeVries. 2017. Feed sorting in dairy cattle: Causes, consequences, and management. J. Dairy Sci. 100:4172-4183. https://doi.org/10.3168/jds.2016-11983.
Nordlund, K. V., and E. F. Garrett. 1994. Rumenocentesis: A technique for the diagnosis of subacute rumen acidosis in dairy herds. Bov. Pract. 28:109-112.

NRC. 2001. Nutrient Requirements of Dairy Cattle: 7th rev. ed. The National Academies Press, Washington, DC

Oliveira, A. S., E. Detmann, J. M. S. Campos, D. S. Pina, S. M. Souza, and M. G. Costa. 2011. Meta-analysis of the impact of neutral detergent fiber on intake, digestibility and performance of lactating dairy cows. Rev. Bras. Zootec. 40:1587-1595. https://doi.org/10 $.1590 /$ S1516-35982011000700026.

Pate, F. M. 1981. Fresh chopped sugar cane in growing - finishing steer diets. J. Anim. Sci. 53:881-888. https://doi.org/10.2527/jas1981 $.534881 \mathrm{x}$.

Pereira, M. N., E. F. Garrett, G. R. Oetzel, and L. E. Armentano. 1999. Partial replacement of forage with nonforage fiber sources in lactating cow diets. I. Performance and health. J. Dairy Sci. 82:2716-2730. https://doi.org/10.3168/jds.S0022-0302(99)75528 $-1$.

Ramli, M. N., Y. Imura, K. Takayama, and Y. Nakanishi. 2005. Bioconversion of sugarcane bagasse with Japanese koji by solid-state fermentation and its effects on nutritive value and preference in goats. Asian-australas. J. Anim. Sci. 18:1279-1284. https://doi .org/10.5713/ajas.2005.1279.

Sá Neto, A., A. W. Bispo, D. Junges, A. K. Bercht, M. Zopollatto, J. L. P. Daniel, and L. G. Nussio. 2014. Exchanging physically effective neutral detergent fiber does not affect chewing activity and performance of late-lactation dairy cows fed corn and sugarcane silages. J. Dairy Sci. 97:7012-7020. https://doi.org/10.3168/jds .2013-7856.

Suarez-Mena, F. X., G. I. Zanton, and A. J. Heinrichs. 2013. Effect of forage particle length on rumen fermentation, sorting and chewing activity of late-lactation and non-lactating dairy cows. Animal 7:272-278. https://doi.org/10.1017/S1751731112001565.

Van Keulen, V., and B. H. Young. 1977. Evaluation of acid-insoluble ash as natural marker in ruminant digestibility studies. J. Anim. Sci. 44:282-287. https://doi.org/10.2527/jas1977.442282x.

Van Soest, P. J., J. B. Robertson, and B. A. Lewis. 1991. Methods for dietary fiber, neutral detergent fiber, and nonstarch polysaccharides in relation to animal nutrition. J. Dairy Sci. 74:3583-3597. https://doi.org/10.3168/jds.S0022-0302(91)78551-2.

Wang, B., S. Y. Mao, H. J. Yang, Y. M. Wu, J. K. Wang, S. L. Li, Z. M. Shen, and J. X. Liu. 2014. Effects of alfalfa and cereal straw as a forage source on nutrient digestibility and lactation performance in lactating dairy cows. J. Dairy Sci. 97:7706-7715. https://doi org $/ 10.3168 /$ jds.2014-7961.

Weiss, W. P. 1998. Estimating the available energy content of feeds for dairy cattle. J. Dairy Sci. 81:830-839. https://doi.org/10.3168/jds .S0022-0302(98)75641-3.

Wells, L. A. 2016. The applicability of near infrared reflectance spectroscopy to predict dry matter intake and in vivo neutral detergent fiber digestibility in mature geldings consuming an all-forage diet. MS Thesis. Department of Animal Science. West Texas A\&M Univ., Canyon, TX.

Zhu, L., C. Jones, Q. Guo, L. Lewis, C. R. Stark, and S. Alavi. 2016. An evaluation of total starch and starch gelatinization methodologies in pelleted animal feed. J. Anim. Sci. 94:1501-1507. https:// doi.org/10.2527/jas.2015-9822. 